International Journal of English Language Studies (IJELS)

ISSN: $2707-7578$

DOI: $10.32996 /$ ijels

Website: https://al-kindipublisher.com/index.php/ijels

\title{
Rhetorical Structure of Ghanaian Tourist Destination E-Brochures
}

\author{
James Kofi Duut ${ }^{1}$ and Emmanuel Kyei ${ }^{2} \square$ \\ 'Odomaseman Senior High School, Sunyani, Bono Region, Ghana \\ ${ }^{2}$ Department of Interdisciplinary Studies, College of Agricultural Education, Mampong-Ashanti, Akenten Appiah-Menka \\ University of Skills Training and Entrepreneurial Development (AAMUSTED), Kumasi, Ghana
}

$\square$ Corresponding Author: Emmanuel Kyei, E-mail: ekyei@aamusted.edu.gh/ okyekye09@gmail.com

\begin{abstract}
ARTICLE INFORMATION
Received: 08 October 2021

Accepted: 07 November 2021

Published: 17 November 2021

DOI: $10.32996 /$ ijels.2021.3.11.3

\section{KEYWORDS}

Communicative purpose(s), Genre, tourism brochure, move structure

\section{ABSTRACT}

Currently, Ghana's economy seems to be relying on income generated from the tourism industry to support national growth. However, interest in tourism appears unattractive as compared to developed countries. It is in the light of this that this research focused on conducting an investigation into one of the main means of persuading potential tourists. This research, therefore, used purposive sampling to select 20 Ghanaian tourist destination e-brochures from the website of the Ghana Tourism Authority. The texts were analyzed using the English for Specific Purposes (ESP), Swales' (1990) genre analysis approach. The purpose was to explore the rhetorical structure of the tourist destination brochures. The results showed that the Ghanaian tourist destination e-brochure could be constructed with seven different communicative functions which constitute its Moves (Identifying Tourist destination, Providing Background Information, Detailing Tourist Destination, Providing Service Information, Soliciting Response, Providing Extra Information, and Urging Action). However, their frequency of occurrence showed that only three of the Moves (Identifying Tourist Destination, Providing Background Information, Providing Service Information) occurred in all the texts. The first four Moves constituted the commonest sequencing pattern of the texts. In terms of length of the texts or textual space given to the Moves, the second Move occupied the largest space of the tourist e-brochures studied. This research has implications for the Ghana tourism industry in improving the rhetorical structure of its brochures and also academic research.
\end{abstract}

\section{Introduction}

One area which serves as a backbone of any developed or developing country is the hospitality and tourism industry (Boakye, 2012; Polkanova \& Kozakov, 2014). Luo and Huang (2015) posit that, over the world, the tourism industry has seen quick growth which has come about partly as a result of publicity in recent times. Irimiea $(2018$, p. 148) adds, —from a timid start-up in the 1950 s and 1960s, tourism education has gained more focus and has acquired a steady growth in the last decades of the $20^{\text {th }}$ century\|. The fast growth of the tourism industry around the world is motivated by its contribution to national budgets (Polkanova \& Kozakov, 2014; Salim et al., 2012). This implies that the role tourism played in the development of nations across the globe was not realized until the 1980s. Polkanova and Kozakov (2014) assert that it was at the beginning of the $21^{\text {st }}$ century that the fastestgrowing markets in the world changed. It is also established that the tourism industry is a crucial area that serves to relieve countries of the burden by creating opportunities for employment and increase in income for personal and local development (Boakye, 2012; Polkanova \& Kozakov, 2014).

Ghana's tourism could be described as a new comer', despite the fact that it was recognized since colonial times. It is described so because of its recent growth and significant contributions to the nation's gross domestic growth (GDP) (Boakye, 2012). Boakye posits that the need to project and develop the tourism sector in Ghana started over two decades ago in order to increase the revenue that could be generated for the development of the country. He contends that Ghana has, indeed, seen a drastic change

Copyright: (C) 2021 the Author(s). This article is an open access article distributed under the terms and conditions of the Creative Commons Attribution (CC-BY) 4.0 license (https://creativecommons.org/licenses/by/4.0/). Published by Al-Kindi Centre for Research and Development, London, United Kingdom. 
in terms of revenue growth from the tourism sector since 2005. The change in growth was evidenced in the key indices - such as arrivals, receipts, number of hotel beds, and employment|| (Boakye, 2012, p. 101). It has been generally acknowledged that a country that pays serious attention to the development of its tourism industry can increase the fortunes of its economy in terms of income and employment generation.

One of the key promotional materials that project a good image of tourist destinations in the tourism industry is the tourist brochure. Boakye (2012) points out that it is now that the tourism industry is making a significant contribution to gross domestic growth (GDP) in Ghana. It is therefore important to pay attention to the study of the tourist brochures in Ghana. However, this genre appears not to have attracted much linguistic research attention. Meanwhile, a thorough investigation and knowledge of the generic structure of the tourist brochure will be very useful in helping the design to promote the general objective of communicating its persuasive purpose to tourists. It is also well-known that the tourist information brochure employs language to communicate its purpose to the potential tourist. Alali (2017) postulates that the English language is conceived as an international language in the domain of trade and advertisement, which is also significant in the promotion of tourism destinations. Due to this, it is important for the tourism advertising agents to use the appropriate language to entice the potential tourist to visit beautiful scenery.

The literature on empirical studies reveals that there has been some research interest in tourism promotional text from the macrolevel. That is to say, the studies that investigated the rhetorical structure of tourism brochures have done so generally from the genre perspective. The overall findings have commonly indicated that there are about eight moves of tourist brochures (e.g., Henry \& Roseberry, 1998; Mongkholjuck, 2008; Luo \& Huang, 2015; Nguoi, 2016). Other studies have indicated a varying number of moves such as three, five, six, and twelve (e.g., Hiippala, 2013; Alali, 2017). In all, some of the identified moves overlap while others share differences, although the same text (tourist brochure) was investigated. These observations suggest that there is subjectivity in the approach. There is also variation in tourist text construction and the kind of interpretation imposed on it.

The study aimed at providing information on the macro-structure, by way of looking at the movement patterns, frequency of occurrence, move to sequence, and textual space of the tourist brochures. Put differently, the main focus of the work is the rhetorical structures of the tourist brochure. The study seeks to provide answers to this research question:

1. What is the typical rhetorical structure of the e-brochures of Ghanaian tourist destinations?

\section{Literature Review}

It has been reading revealed that Ghanaian tourist brochures have received little attention linguistically. So far, we can count on only Bakah's (2010) study which was conducted in French and the language not accessible to many Ghanaians, unlike similar studies from other parts of the globe, especially English L1 contexts (e.g., Iborra \& Garrido, 2001; Kang \& Yu, 2011). Also, some studies have been conducted in the English as Foreign Language (EFL) context or second language environment (e.g., Sinraksa, 2009; Sun, 2009; Alali, 2017). These studies confirm the fact that little is known on the linguistic study of tourist brochures in the post-colonial African settings, like Ghana, where most of such countries struggle in their bid to develop the tourism industry for national development. It will, therefore, be worth studying tourist brochures from the Ghanaian contexts, in order to better understand how the texts are designed to project the persuasive integrity of tourism in Ghana, which will also have a lasting effect on the tourism industry. The genre perspective of analyzing the tourist brochure could reveal the rhetorical strategies of the tourist brochure and the purpose for creating this special promotional text. As accentuated by Afful and Kyei, genre studies present a unique understanding of the nature of writing in both academic and other professional contexts. It has also been stated that genre analysis aids in the comprehension of how a text is structured, as well as providing insights into the flow of texts, their movements, and patterns (See Kyei \& Afful, 2021; Tulud, Mosquera \& Algouti, 2021). Hence, the main purpose of this thesis is to examine the genetic structure of the tourist information leaflet, deploying the genre perspective.

\section{Methodology}

This section presents the methods which were employed in the study.

\subsection{Research Design}

This research employed the qualitative approach. The study used the convenient sampling technique to collect the data. This approach was adopted in order to provide an opportunity for the researcher to gather the necessary data for this particular study because getting access to the hard print tourist brochure was difficult. Apart from the qualitative technique of data collection, the research design was also informed by the kind of analytical approach used. The thesis utilized the ESP genre perspective of identifying the communicative functions of the different organizational structures of the tourist brochure. In simple terms, the research largely adopted the conventional content analysis approach in analyzing the structure of the tourist brochure, which was in line with the analytical approach proposed by Hsieh and Shannon (2005). Generally, the entire work appeared descriptive in nature, although some statistical tools, like percentage and mean, were employed in the analysis and the discussion of the results. 


\subsection{Data and Source}

The data for the study were Ghanaian tourist e-brochures from a number of tourist destinations. The data were available online and were collected from https://visitghana.com. Because the data was in the public domain, there was no_need to pay attention to ethical issues. The source of the data contained different tourist attractions across the country. This choice of information source was made because it is argued that the availability of online information sources provides easy access to tourism destinations in this age of information explosion (e.g., Ip, 2008; Larmolenko \& Schneider, 2016; Salim et al., 2012).

\subsection{Sample Size}

The size of the data for this study was 20 tourist e-brochures which were collected from different tourist attractions across the then ten regions of Ghana through the internet. The total number of tourist attractions was about 40 on the official website of the Ghana Tourism Authority. The choice of 20 e-brochures was informed by the fact that the 20 appeared to have been completed in their construction. In other words, we selected those e-brochures which appeared complete in form. As of the time of data collection, some of the e-brochures were still under construction. Some of them indicated uncompleted sentence structures. We, therefore, relied on the 20 because they could reveal common patterns for the exploration of the typical features of the Ghanaian e-brochures.

\subsection{Sampling Technique and Data Collection Procedure}

The purposive or the convenient sampling technique was used in this research to select twenty e-brochures. This technique was chosen because we wanted to select data samples that could be suitable for the kind of analysis in the study. The initial search for data samples for this study informed the choice of technique to be used because we wanted to use hard print copies of the tourist genre. This required visiting tourist centers to collect samples for the research, which was very difficult because the hard copies were rare. We finally relied on the e-brochures which could be easily accessed from the online site visitghana.com.

\subsection{Method of Data Analysis}

This section discusses the actual method or process that was used to handle the data so as to come out with the findings and results of the study. After gathering the corpus, we coded them for identification purposes. The data were coded TB $(1,2,3,4$ ....20) to make reference to specific data in the presentation of results and discussion section.

\section{Results and Discussion}

This section presents the results and discussion of the data investigated in this research. The research aimed to examine the rhetorical structure of the tourist destination e-brochures in Ghana. It also encompasses the frequency of Move occurrences, Moves sequencing, and textual space.

\subsection{Moves/steps Identification and Labelling}

Based on Swales' approach to analyzing genres in the English for Specific Purposes (ESP) theory, the different communicative functions of the e-brochures were segmented. Although Molina and Esteban (2006) identify two main aspects of the tourist brochure: the content (also destination information) and the attractiveness (image), this part of the work identified different submoves of the tourist destination genre. This section presents the Moves identified in the tourist e-brochures. Move description involves how communicative functions were used to identify the various Moves and the number of Moves identified. It has already been indicated that this study explores only the linguistic aspects of the tourist genre. It is a language that is used to achieve the established communicative functions of a particular genre (Nguoi, 2016). The purposes and examples of the identified Moves are discussed below. Table 1 shows the various Moves (M) and Steps (S) identified and labeled in the data.

Table 1: Move/Steps identification and labeling in the E-brochures

Moves Label Description




\begin{tabular}{lll}
\hline M1 & Identifying Tourist Destination & The name of the destination \\
M2 & Providing Background Information & General background of the site \\
S1 & Description & \\
S2 & History & Information of what to do or see \\
M3 & Detailing Tourist Destination & \\
M4 & Providing Service Information & Extra services rendered \\
S1 & Opening hours & \\
S2 & Accommodation & \\
S3 & Direction & \\
S4 & Entrance fees & Contacting service providers \\
M5 & Soliciting Response & \\
S1 & Address & \\
S2 & Contact number & Nearby tourist sites \\
S3 & E-mail & Reinforcing visitation \\
M6 & Providing Extra Information & \\
M7 & Urging Action &
\end{tabular}

We can see from Table 1 that different communicative purposes have identified seven Moves in the Ghanaian e-brochures of the tourist destinations. These moves were Identifying Tourist Destination, Providing Background Information, Detailing Tourist Destination, Providing Service Information, Soliciting Response, Providing Extra Information, and Urging Action. The moves were identified and labeled with their respective steps. Details of the moves and the steps are provided below.

\subsection{Move 1: Identifying Tourist Destination}

The first Move was identified as Identifying Tourist Destination. This Move provides the labeling of the tourist destination to the potential tourists to explore what a destination contains. This move was communicated without any step. Öztürk and Şiklar (2014) argue that the name of the tourist destination is important due to its ability to draw people closer to the text and the destination.

This Move overlaps with the headline model of promotional genres described by Bhatia (2005) and Kathpalia (1992) because the Move seeks to attract the attention of customers. This comparison was also necessary because Luo and Huang (2015) argue that, in analyzing the tourist rhetorical genre, it is necessary to compare its communicative function to a regular advertisement. This is due to the fact that tourists advertising genres share similar features with those of general advertisements (Ip, 2008). In simple terms, the headings provide the names of the tourist destinations, which were also found in different studies (Henry \& Roseberry, 1998; Luo \& Huang, 2015; Nguoi, 2016; Öztürk \& Şiklar, 2014; Mongkholjuck, 2008; Proborini, 2013). This implies that almost all the tourist e-brochures provided headings that contained enough information to name the tourist destinations and to draw the attention of readers to what the destinations represented. Headings were brief in nature, as can be seen in Extracts 1 to 5 .

\section{Extract 1: Aburi Botanical Gardens \\ Extract 2: Akaa Falls \\ Extract 3: Bonwire Kente \\ Extract 4: Kintampo Waterfalls \\ Extract 5: Zenga (Paga) Crocodile Pond}

We can see from Extracts 1 to 5 that Move 1 is made up of specific names of the various tourist destinations. The names were composed of about four different combinations. Tourist destination names are commonly noun phrases (Öztürk \& Şiklar, 2014). The data show that there are names made from the towns in which the destinations are located. These are exemplified in Extracts 1, 3, 4, and 5. Other examples include destinations such as Elmina Castle, Ada Foah Tourism, Aburi Botanical Garden, and Kintampo Waterfalls. These names tell us about the specific towns where potential tourists can locate the destinations without difficulty. Such names simply offer clear directions to the tourists.

There are other names in Move 1 which are made up of the combinations of renowned personalities who were, one way or the other, directly associated with the creation or discovery of the tourist destinations and what the destinations involved. Such names as Akaa, Fuller and Okomfo Anokye provide readers with some historical events surrounding the destinations right from the start of the names. -Komfo Anokye Sword Site\| as a name, for instance, talks about the historical figure - Okomfo Anokye\| and how he planted the magical sword. The name speaks to what the potential tourists are to expect in paying a visit to the site. In some of the destinations, geographical names were used as labeling markers to draw home the message of what the destinations were 
made up of. Such names include Lake Bosomtwe or Mountain Afadjato. The destination names that begin with geographical labels draw attention to the natural beauty anticipated to attract the potential visitors of such places.

The last combination of names was related to historical missionary events or activities that brought the destination into being, for example, Christianborg Castle. The last labeling pre-informs the reader that such names were not, in the first place, meant for tourist destinations from their creation. However, the names suggest that such places have outlived their initial us efulness, which calls into effect the functional purpose of attracting potential visitors to generate income. In all, most of the names seem selfexplanatory. Öztürk and Şiklar (2014) indicate that single names of tourist destinations are insufficient to attract customers. The nature of the Ghanaian tourist destination names fulfills the general purposes of this genre expressed by Proborini (2013) that brochures have three characteristic features which are used to achieve three different purposes: Information, Advertising, and Identification. This is based on the fact that the contents of the names inform, advertise, and identify the destination to tourists. The names create some image of a destination to the potential visitors (Luo \& Huang, 2015).

In all, Move 1 communicates briefly to potential visitors to make a quick judgment about what they intend to read to visit a particular tourist destination. This is based on the fact that simple names used help readers to easily make decisions (Kang \& Yu, 2011). It also means that the choice to select a particular destination partly relies on the name the destination presents. In simple terms, the name introduces the destination to potential tourists and latently advertises the content of the destination right from the beginning.

\subsection{Move 2: Providing Background Information}

The purpose of the second Move was to provide background information about the various tourist destinations. Move 2 offers the opportunity for readers to understand detailed background information of the various destinations. This Move was created through two steps: Description and History. The destination background information details readers about the description and the nature of the destinations. The Description step provides general information about what a particular tourist destination is about. Some of the background information is based on historical facts. Most of the destinations provide information about the historical antecedents of beautiful places and their people, which was also found in similar studies (Henry \& Roseberry, 1998; Nguoi, 2016; Mongkholjuck, 2008; Proborini, 2013). The existence and the origin of the destinations are known through Move 2. Some of the historical details transcend the history of the destination and reveal more information about the beginning of the people and the surrounding towns or even the country. Readers also get to know the traditions and the belief systems of the people who occupied the areas in some of the destinations, especially those about tradition, heritage, or castles. In fact, such destinations can be described —historical record keepers.

After reading the background information of the destinations and before visiting the place, readers seem to get a sense of reliving and experiencing the moments of what happened in the past. It means that the information in Move 2 intensifies the eagerness to visit the destination to experience the reality on the grounds. It also motivates readers to pay a visit to relive past experiences the destinations hold and be part of their creations. Extracts 6 to 8 illustrate the nature of Move 2 .

Extract 6: Nchiraa Waterfalls is located 30 kilometers north of Wenchi in the Brong Ahafo region of Ghana. Nchiraa waterfalls are wedged between the mountains of the Nchiraa settlement.

\section{History}

In the early 2000s, one Kofi Asiama, a hunter, during his tracking, discovered the waterfall which is about two kilometers into the forest. During one of the usual rural afternoon sittings at drinking bars, he gave an account of his expeditions, revealing an attractive depiction of a site he saw in the bush. Some residents who had visited the Kintampo Waterfall and acknowledged its recreational importance expressed interest to see the new discovery in their own backyard.

The hunter, therefore, led a delegation to the place in 2004, and thereafter a management committee with Emmanuel Obour Adjei as chairman was constituted to among other things promote and possibly seek a strategic investor to develop the beautiful feature into a preferred tourism destination.

Nchiraa Waterfalls offers the tourist a hiking adventure on a rocky and challenging footpath that leads to the waterfall. The existence of other natural and cultural tourism attractions within a $10 \mathrm{~km}$ radius makes the tour package exhilarating. (Nchiraa Waterfalls)

Extract 7: St George's Castle, a UNESCO heritage site, was built as a trading post by the Portuguese in 1482, and captured by the Dutch in 1637. It was expanded when slaves replaced gold as the major object of commerce, with storerooms converted into dungeons. The informative tour (included in the entry fee) takes you to the grim dungeons, punishment cells, Door of No Return, and the turret room where the British imprisoned the Ashanti king, Prempeh I, for four years. 
Elmina Castle was the first trading post built on the Gulf of Guinea, so is the oldest European building in existence in sub-Saharan Africa. Elmina is also a picturesque fishing town along Ghana's coast, not far from Cape Coast. It is home to one of Ghana's biggest attractions, St George's Castle. Built by the Portuguese in 1482, it was captured by the Dutch 150 years later and became the headquarters of their West Indies Company for the following 250 years... (Elmina Castle)

Extract 8: Situated on the grounds of the Komfo Anokye Teaching Hospital, Kumasi, is the Komfo Anokye Sword Site which is seminal in Asante history. A 333-year-old sword wedged in the rockface is one of the center artifacts and legends of the rich history of the Asante nation. The history of the Asante people is eloquently told by the young curator. On a good day, you may run into the Asante king who regularly comes to pay his respects at this important and sacred site.

A tour of the site offers one great insight into the beginning of the Ashanti Kingdom. The landmark has been protected for future generations. This site is a historical landmark where the Legendary Okomfo Anokye Sword is cited.

The Sword site is the exact place where the Golden Stool of Asanteman descended unto the laps of King Osei Tutu I, -Opemsuo|| the founder of Asante Nation. The site was predicted by Okomfo Anokye to be a healing place for millions of people.

Lo and behold, the site happens to be the exact place where the Komfo Anokye Teaching Hospital is situated.

One fascinating story about the Sword is that, since it was planted in 1695, countless attempts had been made to remove it from the ground but to no avail.

The 'immovable' Sword driven into the ground by Okomfo Anokye remains and is the venue of the Okomfo Anokye Teaching Hospital. History has it that the sword was pushed into the ground, almost 300 years ago. It is believed the Okomfo pronounced that no one would be able to remove the sword, and so it has remained in spite of attempts. The Ashanti state, it is believed, would collapse should the sword ever be pulled out of the ground. (Komfo Anokye Sword Site)

The background information provided in Extracts 6, 7, and 8 orients us about the existence of a waterfall, castle, and magical sword respectively. Extract 6 illustrates the background information of Nchiraa Waterfalls, describing its discovery, location (30 kilometers north of Wenchi in the Bono Region), and nature. Extract 7 describes a heritage site (Elmina Castle) which originally was not meant for tourism. The information provides details about the early activities of the coming of the Europeans to Ghana. It means that the original purposes of castles and forts were not meant for tourism but colonial activities such as slavery, trade, missionary, or expedition. Because such castles have outlived their original purposes, they have been turned to serving an economic purpose to the nation, through tourism. Extract 8 (Komfo Anokye Sword Site) details the early life of the Ashanti Kingdom, their traditional practices, and belief systems.

These cultural heritage sites preserved in the historical narratives of the tourist e-brochures reveal the cultural values of the people around them (Palkanova \& Kozakov, 2014; Salim et al., 2012). It is this kind of organization of culture and social purposes of language that is connected to a genre (Bhatia, 1993; Swales, 1990). The e-brochure provides interesting information for readers to acquire knowledge and enjoy the details and history of the destinations at any convenient place because the information can be accessed online. This Move is similar to Justifying the Product or Service by indicating the nature and the importance of the promotional genre as established by Bhatia (2005) and Kathpalia (1992). Luo and Huang (2015), however, did not identify this Move.

\subsection{Move 3: Detailing Tourist Destination}

The identification of this Move was based on Detailing the Produce/Service by Bhatia (2005) because promotional genres indicate the value of a product or service by identifying it, describing what it offers to customers to patronize. This Move provides detailed information about the interesting facilities of the destinations to readers and potential visitors. It is about the details of what the various destinations offer the potential tourists on their available facilities, activities, or specialties. The purpose of this Move is to offer space for the satisfaction of desire or curiosity. This is the central Move which forms the main idea of visiting the tourist destinations. It is basically about the main events, activities, or attractive sceneries for traveling to have first-hand information about what visitors read and hear about the various destinations. This Move on the e-brochures details the potential visitor about specific things he/she can do or experience upon visiting the destination. Extracts 9 to 12 show the nature of Move 3 in the ebrochures: 


\section{Extract 9:}

o Stop at the Visitor Centre to arrange your tour, enjoy a beverage in the open-air and meet your guide.

o The weaving tour includes a visit to the community Kente workshop, where you can learn and try how to thread spinning, warping, and weaving.

- Visit village shops selling Kente products and other village crafts.

o Meet master weavers and learn the different types and systems of weaving.

o Tour the village of Bonwire and see village residents engaged in the various stages of Kente production using traditional handlooms.

o Take a tour to see the different types of yarns used in the production of unique designs of Kente. (Bonwire Kente)

\section{Extract 10: What to do}

- See the photo display of great Ghanaians such as Azumah Nelson, Efua T. Sutherland as well as other PanAfricanist.

- Visitors may take great interest in memorable sights such as the credential rooms used by the former British officials and former Ghanaian presidents, slave dungeons, walkway to the Door of No Return, a water reserve, and a chapel sometimes used by the

- Visitors would be given the opportunity to take photographs of the captivating seashore, fishing boats, extensive gardens with a wide variety of plants, and the township by the castle.

- The castle allows visitors access to a car park and walkway around the gardens.

- Visit the nearby excavated sections to see artifacts. (Christiansborg (Osu) Castle)

\section{Extract 11: What to do at Lake Bosomtwe}

There is an information center, where you can find out about the lake and conservation efforts, and also arrange for a boat trip on the lake. If you are lucky, someone will open a coconut or two for you for a few cedis.

It is possible to take boat rides on the lake, swim, and hike around. The various communities around Lake Bosomtwe are very welcoming. There are also some great hikes up into the hills and the sacred areas around villages. (Lake Bosomtwe)

\section{Extract 12: Things to do at Akaa Falls:}

- An exciting view of the scenery and the water dropping off the cliff

- A nice seasonal bath at the edge of the cliff

- A get together on the dry ground (Akaa Falls)

Extracts 9, 10, 11, and 12 illustrate the Detailing Tourist Destination Move, which provides detailed information about what potential tourists can experience. Extract 9 shows interesting activities that go on at the destination, the adorable artefacts visitors can see and buy for themselves there and the processes involved in manufacturing Kente. In Extract 10, visitors are guided to know interesting things they can see by a way of reliving past experiences of slavery and historical antecedence that took place in the Osu Castle. Apart from the historical sight of the castle, Move 3 of Osu Castle provides potential visitors information about what they can enjoy around the surroundings of the castle, as part of satisfying their curiosity and desires. Extract 11 shows what visitors will see and do when they get to Lake Bosomtwe for tourism. We noted from this extract that visitors can see the natural sight of the lake, take a boat trip or ride on the lake and find some fruits around to enjoy during their short moment stay. Extract 12 taken from Akaa Falls also promises potential visitors an exciting bath and the nice scenery of the falls. In fact, all these extracts explain why the visitors should spend some amount of money on entertaining and relieving stress.

Move 3 is similar to other studies found (Henry \& Roseberry, 1998; Luo Huang, 2015; Nguoi, 2016; Mongkholjuck, 2008; Proborini, 2013). It creates a good image of the tourist destination because the image is embedded in the artistic and monumental heritage, good range of entertainment facilities available for value for money (Vareiro et al., 2019). It is the quality of image the destinations create that attracts the potential tourist to revisit a place (Polkanova \& Kozakov, 2014; Vareiro et al., 2019).

\subsection{Move 4: Providing Service Information}

The main function of this Move is to provide information related to what it takes to enjoy the various tourist destinations. This section of the e-brochure provides information on location, mileage, direction, transportation, accommodation, feeding and refreshment, operating hours, and service charges or entrance fees. These different elements of Move 4 constituted four different steps: Opening Hours, Accommodation, Direction, and Entrance Fees. This particular Move offers detailed information for potential visitors to prepare in advance before visiting the place, in terms of money and any other relevant issue. It helps the will-be visitors 
to decide either to pay a visit or not because it involves one's ability to afford to patronize a particular destination. Some of the service information is provided in Extracts 13 to 15.

\section{Extract 13: Opening Hours}

The castle's opening hours are 9:00 am to 4:30 pm daily.

\section{Entrance fees are as follows:}

\begin{tabular}{ll}
\hline Visitor Category & Entrance Fee \\
Pupils from Primary to JHS 3 & $\mathrm{GH} ₫ 1.00$ \\
SHS Students & $\mathrm{GH} ₫ 2.00$ \\
Tertiary Students with ID & $\mathrm{GH} ₫ 3.00$ \\
Ghanaian Adults & $\mathrm{GH} ₫ 5.00$ \\
Foreign Children & $\mathrm{GH} ₫ 5.00$ \\
Foreign Students with ID & $\mathrm{GH} ₫ 30.00$ \\
Adult Foreigners & $\mathrm{GH} ₫ 40.00$
\end{tabular}

\section{Extract 14: When to Visit}

(Cape Coast Castle)

Visit Bonwire any time of the year. Bonwire Weaving Centre opens from 9 am to 5 pm. Bonwire Kente Festival is also held each year where new designs are outdoors.

\section{Accommodations, Food, and Refreshments}

Homestays accommodation is available in the village. There are a variety of hotels available in Ejisu and Kumasi $19 \mathrm{~km}$ away. Meals are available for delivery on order. Liquid refreshments are also available in the village.

\section{Hours}

8 am to 5 pm daily

\section{Getting there}

From Accra, take the Accra-Kumasi road turn right at Ejisu, and drive $6 \mathrm{~km}$ to the Bomfa Junction. Turn left and drive $3 \mathrm{~km}$ to turn right to Bonwire. (Bonwire Kente)

\section{Extract 15: $\quad$ When to Visit}

Visit Avu Lagoon any time of year. Birds are more active and vocal at dawn and dusk.

\section{Accommodations, Food, and Refreshments}

For those visitors who would like to spend more than a day at Avu Lagoon, a comfortable home-stay option is available (showers, flush toilets, fans, lights, sheets, but not towels). Meals are available from community cooks and liquid refreshments are also available in the village.

\section{Hours}

8 am to 5 pm daily

\section{Directions}

From the main Accra road, watch for Avu Lagoon ecotourism project signs at Dabala junction then turn right drive to Dabala then you will see other signs leading to Tosukpo where the welcome sign and tour guides will be. The second option is from the main Accra-Aflao road at Akatsi, turn right onto the dirt road, and follow signs for $18 \mathrm{~km}$ (approximately 20 minutes) to the visitor center at the entrance to the village. Trotros are available from Accra and Ho. Local taxis are available from the Akatsi market along the dirty road to the Avu Lagoon visitor center. (Avu-Lagoon Xavi)

Extract 13 gives service information about the opening hours and entrance fees for visiting Cape Coast Castle. We also get to know the operating hours, accommodation, feeding and refreshment, direction, and mileage of visiting Bonwire Kente in Extract14. Extract 15 details readers of the appropriate time to visit Avu Lagoon, location, and direction to the place, as well as the mileage involved. All the information provided by Move 4 guides readers and visitors to plan their trip to the tourist centers before embarking on their expedition.

Providing important information such as location, mileage, direction, transportation, accommodation, feeding and refreshment, operating hours, and service charges or entrance fees gives the potential tourists the opportunity to make advance preparations 
before embarking on visiting a chosen tourist destination. Other similar studies found the same results (Henry \& Roseberry, 1998 ; Luo \& Huang, 2015; Mongkholjuck, 2008; Proborini, 2013). Cautions about the dangers of visiting the destinations are also provided for visitors to avoid accidents and injuries. It is argued that all these factors can influence the image of a destination because providing detailed information on safety and security, accommodation, feeding, transportation, and other important factors indicate the quality of a destination (Palkanova \& Kozakov, 2014; Salim et al., 2012; Vareiro et al., 2019; Williams \& MacLeod, 2006). Providing Service Information confirms one of the three main functions (information, advertising, and identification) of the tourist brochure as advertising and informing functions, which seeks to provide information on the sights, activities, location, cost, and other relevant information about the tourist destination (Hiippala, 2012).

\subsection{Move 5: Soliciting Response}

Because one of the features of promotional genres is to encourage further communication (Bhatia, 2005), this part of the ebrochure was identified as Soliciting Response. Move 5 has the communicative function of interacting with the service providers, in this case, tourist centers for any inquiry. Three steps were identified in this Move: Address, Contact Numbers, and E-mail. The Move provides contact details of the service providers by which potential visitors can interact through a contact address and contact numbers. When visitors are able to interact well with the tourist service providers, customers' views about their experiences can be shared, using any of the social media platforms for better improvement of the destinations. Three means of communication (i.e., contact address, e-mail address, and contact address) were found in the e-brochure texts. Extracts 16 to 20 are examples of how the service providers constructed this Move.

Extract 16: Contact

Avu Lagoon Ecotourism Project, P.O. Box 6, Akatsi,

Volta Region, Ghana; 024-2015329 (Avu-Lagoon Xavi)

Extract 17: $\quad$ Contact

+233208424317 (Akaa Falls)

Extract 18: $\quad$ Contact Details:

GMMB

Central and Western Regions

Cape Coast Castle

Cape Coast

Tel +233-3321-32529/ 03321-32701 (Cape Coast Castle)

Extract 19: $\quad$ Contact Details:

GMMB

2 Barnes Road, Adabraka, Accra

P.O. Box GP 3343, Accra

Telephone: +233-302 221633/221635

Fax: +233-302 222401

E-mail Address: gmmb-acc@africaonline.com.gh

(Christianborg Castle)

Extract 20: $\quad$ Contact Details:

Ghana Museums \& Monuments Board

Central and Western Regions

Cape Coast Castle

Cape Coast

+233576689142

Tel +233-3321-32529/ 03321-32701 (Elmina Castle)

We find that Extracts 16, 18, 19, and 20 contain both contact addresses and contact numbers of the tourist destinations. The only extract that has an e-mail address in addition to the contact address and number is 19. Every e-brochure contains either contact numbers and/or the address of the tourist destination, for potential customers to get in contact with the service providers of a particular tourist destination in Ghana. From Extracts 16 to 20, it is only Extract 17 that has a contact number without any contact address. It implies that contact number is a compulsory element of this Move, unlike address. This might be due to the fact that visiting a tourist destination can take place within a short period of time, but communicating through address may delay the process, as letter writing appears to lose its usefulness in this current dispensation in Ghana. 
Move 5 (Soliciting Response) is in line with Bhatia's move-structure model of advertising or promotional genres. While some studies identified this Move (e.g., Luo \& Huang, 2015; Mongkholjuck, 2008), others did not (e.g., Bhatia, 2005; Henry \& Roseberry, 1998; Nguoi, 2016; Proborini, 2013). This Move is a requirement because potential tourists need to interact easily with the various tourist destinations through the use of modern technology, e-mail addresses, and social media platforms (Luo \& Huang, 2015). However, from all the tourist e-brochures studied, none of them was found to contain information about any social network such as Facebook or Twitter. Meanwhile, Luo and Huang (2015) claim that this particular Move (Soliciting Response) has social networking as a common part of tourist brochures around the globe. It is through social networking that visitors provide feedback on their experiences to the service providers of the various tourist destinations. Visitors are able to share their expectations for improving their previous services.

\title{
4.7 Move 6: Providing Extra Information
}

Move 6 provides information that is not directly about the advertising destination. The extra information is about other tourist destinations which are somehow close to the advertising destination. This Move performs a latent persuasive function to the tourist destination inviting potential visitors to patronize their services. Destination texts highlight these extra destinations probably because they inform the potential tourists of not only making time for a specific place but also several other interesting places and activities that will suffice their use of resources to travel to such places. Most names of such destinations are provided in hyperlinks for potential visitors to access them easily online. Such attractions are described as nearby, informing the customer of how useful it will be to achieve different purposes within the same time. Some of them give an extra good image to the destinations which are advertising because some of the nearby attractions have - bigger\| names. We can see examples of Move 6 in Extracts 21 to 24.

\author{
Extract 21: Nearby Attractions \\ o Tagbo falls \\ - Tafi Atome Monkey Sanctuary

\section{Other Highlands} \\ 1. Aburi Mountain, \\ 2. Odweanoma Mt (Kwahu)
}

\author{
Extract 22: Nearby Attractions \\ Cape Coast Castle \\ Kakum National Park \\ UPPER Fort St Jago / Fort Conraadsburg \\ Forty San Sabastien \\ Ahanta Waves Surf School (Elmina Castle)
}

(Mountain Afadjato)

Extract 23: Nearby attraction

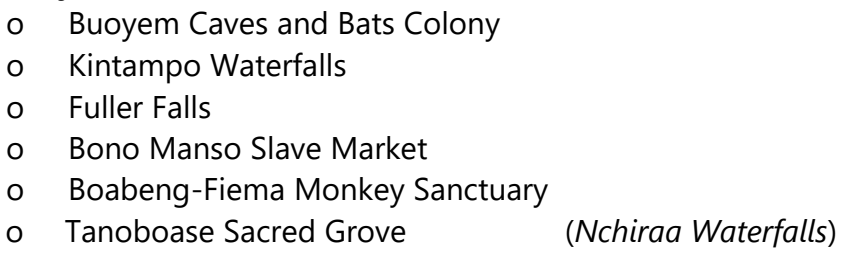

Extract 24: Nearby Attractions

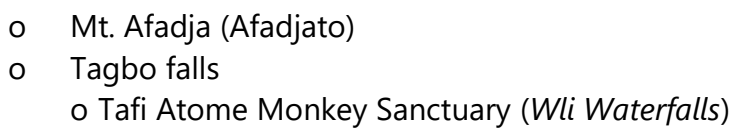

It can be seen that the extracts provided under Move 6 are generally about other tourist sites or destinations that are relatively closer to the respective advertising destinations. The common headings given to such parts of the tourist e-brochures include nearby attractions or other highlands, as can be seen from Extracts 21 to 24. We can also see that most of the names or destinations provided are in hyperlinks for tourists to easily navigate their ways to such sites or destinations for more information about them. This can inform the potential visitors that, after visiting, there are close-by destinations that also offer opportunities to continue the exploration of tourist destinations across the nearby region. Move 6 appears to serve as bait for visitors who are interested in a particular nearby tourist destination to take advantage of visiting the advertised destination. From Table 2, only four tourist destinations out of 20 did not provide information on this Move. This means that the Move is somehow important to persuade 
customers to patronize and explore exciting places. It is also possible that the extra information is provided because most of the destinations do not offer opportunities to stay for days to enjoy themselves but only a day's visit, unlike most foreign tourist destinations.

This Move is not commonly discussed in describing the various communicative functions of the tourist brochure in the literature. Öztürk and Şiklar (2014) observed that the extra information is sometimes not properly arranged in the tourist brochure, such that it can be fused in the actual description of the destination facilities. The silence may also be due to the fact that doing that sounds advertising for others more.

\subsection{Move 7: Urging Action}

This Move was labeled as a separate Move because it is usually used as a persuasive strategy to encourage people to visit a tourist destination, by providing potential reasons for visitors to consider visiting the centers. In most instances, this Move was located at the bottom of the e-brochure. It mostly serves as a teaser to attract the potential reader or customer to take the opportunity to visit the destinations. Examples of this Move can be seen from Extracts 25 to 28:

\section{Extract 25: Don't Miss This!}

Help to protect the endangered sea turtles, their eggs, and hatchlings from predation by animals and villagers by participating in evening beach tours and conservation efforts at the visitor center in Beyin. (Nzulezu Stilt Village)

\section{Extract 26: Don't Miss This!}

Watch for the rarely-seen sitatunga, the world's only aquatic antelope and virtually extinct in West Africa. If surprised, it will submerge with only its nostrils out of water. (Avu-Lagoon Xavi)

\section{Extract 27: Don't Miss This!}

Plan your visit to coincide with Liati Wote's Afadjato Festival, held every August to celebrate the mountain with a variety of events. (Mountain Afadjato)

\section{Extract 28: Don't Miss This!}

Arrange a tour of the fascinating Chief's compound with its maze-like architecture. Go —crocodile riding $\|$ at the back of these wild but friendly crocodiles. You can even lift their tails. (Zenga Crocodile Pond)

The headings of such pieces of information to potential tourists are constructed in the imperative mood, as can be seen from Extracts 25 to 28. This kind of mood does not allow the reader of the text space to reject the offer of visiting what is projected on the text. Extracts 25 to 28 also demonstrate that potential visitors need to do something about the visit or the destination to either save life or enjoy something, using expressions such as help to protect (Extract 25), watch for (Extract 26), plan for your visit (Extract 27) and arrange a tour (Extract 28). All these expressions communicate to the will-be visitors the urgency and the need to do something for nature or themselves. After presenting background information and detailing the destination about its facilities available, this Move is packaged as the summary of the whole destination in a few expressions to highlight the special item that cannot be missed. This particular Move seems to re-echo the central need to visit the destination because it appears to tease the reader of losing something.

Molina and Esteban (2006) suggest that the image or the attractiveness of a brochure must include inviting and funny appeals, in order to entice potential tourists because this genre is a selling-oriented tool to a business or tourist destination. Bhatia (2005) and Kathpalia (1992) agree that this part of a promotional genre is relevant to reinforce the decision of customers to patronize a product or a service. This Move also looks like the application of pressure tactics to entice customers. Few studies (e.g., Kathpalia, 1992; Nguoi, 2016) also identified this move. Öztürk and Şiklar's (2014) study found that this Move was fused into describing the background of the tourist destinations and that it was not labeled as a separate Move. Although not all the e-brochures contain this Move, it offers the motivation meant to influence the decision of potential visitors to pay a visit because the ability of a tourism destination to compete in the tourism market space is largely dependent on its attractiveness and entertaining power (Palkanova \& Kozakov, 2014). This Move reinforces the advertising power because most traditional forms of promotion focus on presenting information and promotion in order to entice the customer by selling ideas, goods, or services (Bhatia, 2005).

The results in this study indicate that the Ghanaian tourist e-brochures were made up of seven moves. Although other studies in the literature identified more than seven Moves, some of their Moves overlap with what is described in this present study, especially on name identification, background information, facilities/activities available to tourists, and soliciting responses (see Henry \& Roseberry, 1998; Kathpalia, 1992; Luo \& Huang, 2015; Nguoi, 2016; Mongkholjuck, 2008; Proborini, 2013). Most of such studies relied more on the headings of the brochures in identifying and describing their Moves, which led to the many Moves than the present research. However, there were other Moves in foreign tourist brochures which were not found in the texts studied in this 
research. Some of them include targeting the market which is more related to defining keywords of tourism, offering incentives to visitors who come along with more tourists, or establishing credentials by way of endorsement by popular personalities. Whatever moves are identified in each case, the most important thing is that the Moves come together to perform informative and persuasive functions to attract potential tourists to visit such interesting conserved places (Hiippala, 2012; Molina \& Esteban, 2006; Proborini, 2013; Sinraksa, 2009).

Sinraksa (2009) indicates that a tourist e-brochure has the ability to arouse the interest of visitors and tourists to visit attractive places because it exhibits the features of what Bhatia (1993) has espoused as characteristics of promotional genres. It is also important to note that the success and quality of events are based on the best and skillful ways of combining the different parts of the event, in terms of settings, service, people, and its management system (Getz \& Carisen, 2006). It means that the effective combination of the seven identified Moves leads to the dissemination of quality of information to customers. Details of the Move description, explanation, and exemplifications are presented below.

\subsection{Frequency of Occurrence of the Moves}

The frequency of occurrence of moves in the e-brochures is the number of times the identified Moves occurred in the texts. The frequency of how the Moves occurred in the text was very important due to the fact that it could provide a way of identifying the common structure used by all the destinations in convincing their potential readers to visit their respective destinations. In simple terms, it brings out the typical features of the destination e-brochures based on common recurring patterns. The distribution of the Moves and steps was counted based on their frequency in all the data used for this research, which were also converted to percentages for easy understanding. The results of the frequency of the occurrence of the Moves are presented in Table 2.

Table 2: Frequency distribution of the Moves/Steps in the e-brochure

\begin{tabular}{lll}
\hline Moves/Steps & Frequency (20) & Percentage \\
\hline M1: Identifying Tourist Destination & 20 & 100.00 \\
M2: Providing Background Information & 20 & 100.00 \\
S1: Description & 19 & 95.00 \\
S2: History & 10 & 50.00 \\
M3: Detailing Tourist Destination & 15 & 75.00 \\
M4: Providing Service Information & 20 & 100.00 \\
S1: Opening hours & 12 & 60.00 \\
S2: Accommodation & 17 & 85.00 \\
S3: Direction & 16 & 80.00 \\
S4: Entrance fees & 5 & 25.00 \\
M5: Soliciting Response & 10 & 50.00 \\
S1: Address & 4 & 20.00 \\
S2: Contact number & 11 & 55.00 \\
S3: E-mail & 1 & 5.00 \\
M6: Providing Extra Information & 16 & 80.00 \\
M7: Urging Action & 6 & 30.00 \\
\hline
\end{tabular}

Table 2 shows that not all the Moves occurred in all the 20 texts studied. Clearly, only three of the Moves occurred in all, representing 100\% each. These Moves are M1 (Identifying Tourist Destination), M2 (Providing Background Information), and M4 (Providing Service Information). Under Move 2, the steps Description and History occurred 95\% and 50\% respectively. It means that almost all the background information had some information to describe what the tourist destinations were about. The occurrence of historical background means that half of the tourist e-brochures presented the history behind the destinations. Again, Table 2 indicates that Move 4 also had four steps: Opening hours, Accommodation, Direction, and Entrance fees. In all the e-brochures studied, only three of them did not indicate accommodation on them. Eighty percent of them showed directions to the respective tourist destinations. Sixty percent of them also indicated the appropriate time or opening hours for potential tourists to visit the destinations. Although tourist sites demand money before allowing visitors to enjoy facilities available, only 5 out of the two e-brochures showed the entrance fees for visitors to prepare in advance.

According to Hüttner (2010), the three most occurring Moves (M1: Identifying Tourist Destination, M2: Providing Background Information, and M4: Providing Service Information) can be described as obligatory moves. Hüttner's (2010) classificatory model indicates that genre exemplars occurring between $90 \%-100 \%$ is considered obligatory move, core move (50\% - $89 \%$ ), ambiguous move (30\% - 49\%), and optional (1\% - 29\%). The three Moves (1, 2, and 4) were described as obligatory because such moves are from the typical features of a given genre and that any Ghanaian tourist destination e-brochure will be inappropriate without these obligatory moves. Consequently, the Ghanaian tourist destination genre could not be described without indicating the name of a 
destination, without the background information, and lastly what a particular destination offers the potential tourists. The classificatory model also suggests that Moves 3,5, and 6 are considered core moves because they occur between $50 \%$ to $80 \%$. However, what is ambiguous is Move 7 (Urging Action) which gives a teaser to reinforce the invitation extended to potential tourists.

The frequency of Moves 1, 2, and 4 coincides with Proborini's (2013) finding that the most dominant Moves include headings, location description, place of information, facilities, and supplementary information. In contrast, Nguoi (2016) found appraising the product, establishing credentials, offering incentives, and urging action as the most frequent Moves in tourist destination brochures, but identification Move occurred 83\%. In Alali's (2017) comparative study, only the finding on the heading shares similar results with this present research. All the general persuasive features of tourist brochures communicate effectively to readers (Coltman, 1989; Molina \& Esteban, 2006). However, the occurrence of these three Moves gives the sense of them being compulsory and that tourist brochure text constructors cannot design the e-brochures without them. This may be due to the fact that the quality of professional service (through M4) and entertaining facilities (through M1 and M2) can greatly influence the choice of destination (Vareiro et al., 2019). It may also be that every e-brochure of tourist destinations realized the need to provide its identity (through M1), demonstrate some background information of the destinations, and provide enough service information for potential tourists to plan in advance before arriving at the destinations or to decide on whether to pay a visit or not based on the conditions provided.

Move 3 (Detailing Tourist Destination) and Move 6 (Providing Extra Information) occurred $75 \%$ and $80 \%$ respectively, as the next highest of occurrence. This means that most of the destinations wanted their readers to understand what could be offered to the visitors. It is also about other sceneries or destinations they can patronize should they plan to pay a visit. Although Providing Extra Information (M6) and Urging Action (M7) did not appear much in all the texts, they are strategies of influencing potential visitors to visit a destination because they are means of competing in the market space for more customers (Palkanova \& Kozakov, 2014). It was also surprising to see that some of the e-brochures did not indicate the specific attraction the destinations had to offer the potential tourist, denying them the specific activities they could enjoy.

We can also see that M5 (Soliciting Response) occurred in half of the e-brochures to indicate that, maybe, there was no need to contact destination service providers before and after visiting. However, making inquiries and providing feedback for future improvement are very important issues to consider. It also means that one will find it difficult to contact the destination service providers should there be any change of plan or activity. Another important communicative function that emphasizes the need to visit and could motivate readers to visit a particular destination was the teaser contained in some of the brochures. Only six of them (30\%) featured this Move (Urging Action). This particular Move draws attention to what cannot be missed should one decide not to pay a visit to a destination. Some destinations did not emphasize M7 because detailing the tourist destination could provide enough information for readers to decide what to do.

\section{10 Sequencing of Moves in the Tourist E-Brochures}

In genre analysis, text sequencing refers to the occurrence of Moves in a certain order to typify the texts in focus. The frequency of common sequence is often relied on to identify the typical features of a genre. By this, the ones that appear common among the various sequencing patterns are used. It does not mean that the common structural sequencing should run through all the texts before we can establish their typical features in terms of sequencing.

This part of the research concentrates on how the tourist e-brochures organized their respective Moves. Identification was done based on how the Moves occurred on each of the e-brochures. This was to find the common pattern that appeared typical of ebrochures in the Ghana tourism industry. This was done to contribute to the identification of the typical features in respect of the rhetorical structure of the tourist destination e-brochure in Ghana. Table 3 gives details of the various sequencing patterns derived from the data.

Table 3: Move sequencing in the e-brochure

\begin{tabular}{lll}
\hline No. & Text & Move sequence \\
\hline 1 & Aburi Botanical Gardens & M: 1-2-3-4-6-4 \\
2 & Ada Foah Tourism & M: 1-2-3-4-6 \\
3 & Akaa Falls & M: 1-2-3-4-5-6-4 \\
4 & Avu-Lagoon Xavi & M: 1-2-3-4-5-7 \\
5 & Bonwire Kente & M: 1-2-3-4-5 \\
6 & Cape Coast Castle & M: 1-2-4-5 \\
7 & Christiansborg Castle & M: 1-2-3-4-6-5 \\
\hline
\end{tabular}




\begin{tabular}{lll}
\hline 8 & Elmina Castle & M: $\mathbf{1 - 2}-\mathbf{3}-\mathbf{4}-5-6$ \\
9 & Fuller Falls & M: $1-2-6-4-5$ \\
10 & Kakum National Park & M: 1-2-3-4-5-4-6 \\
11 & Kintampo Waterfalls & M: 1-2-3-4-2-4-5-2-3-4-6 \\
12 & Komfo Anokye Sword Site & M: $1-2-4-6$ \\
13 & Kpetoe Kente Weaving Vil & M: 1-2-3-4-7 \\
14 & Lake Bosomtwe & M: 1-2-3-4-6 \\
15 & Mountain Afadjato & M: 1-2-3-4-6-7 \\
16 & Nchiraa Waterfalls & M: $1-2-6-4$ \\
17 & Nzulezu stilt village & M: 1-2-3-4-6-4-7 \\
18 & Tini Waterfalls & M: 1-2-5-4 \\
19 & Wli Waterfalls & M: 1-2-3-4-6-7 \\
20 & Zenga Crocodile Pond & M: 1-7-2-3-4-7-6 \\
\hline
\end{tabular}

Table 3 shows that the sequencing of Moves in the texts is differently distributed. Although there are common patterns of occurrence, we can see that the first four of the Moves (1-2-3-4) occur consistently in 14 of the e-brochures (Aburi Botanical Gardens, Ada Foah Tourism, Akaa Falls, Avu-Lagoon Xavi, Bonwire Kente, Christiansborg Castle, Elmina Castle, Kakum National Park, Kintampo Waterfalls, Kpetoe Kente Weaving Village, Lake Bosomtwe, Mountain Afadjato, Nzulezu Stilt Village, and Wli Waterfalls $s_{1}$, despite the fact that there is the presence of other notable Moves occurring after the identified pattern. This means that the regular four Moves which occurred in 14 of the texts were Identifying Tourist Destination (M1), Providing Background Information (M2), Detailing Tourist Destination (M3), and Providing Service Information (M4). This implies that the commonest sequencing occurred such that, after introducing the various tourist destinations through the names, the texts presented their respective background information; gave the details of the destinations as to what they could offer the potential tourist; and provided the details of how one could prepare and get there to enjoy the services and facilities available. The common sequencing (M1-M2-M3-M4) may be due to the fact that the text constructors sought to inform and attract potential tourists about the destination through the name, some information of how the destination came into existence, what services they provide, and details of accessing the destination. It is these recurrent social actions and the recurrent rhetorical situation of a genre that takes place in specific discourse communities that help the members to recognize the typical rhetorical features (Miller, 1984; Swales, 1990).

Besides, the addition of Move 6 (Providing Extra Information) to this identified sequencing of occurrence of the Moves offers another pattern in seven of the e-brochures (Aburi Botanical Gardens, Ada Foah Tourism, Christiansborg Castle, Lake Bosomtwe, Mountain Afadjato, Nzulezu Stilt Village, and Wli Waterfalls). This means that the Move sequencing M1-M2-M3-M4-M6 occurred as the second common pattern in the texts studied, although there were additional Moves to this pattern in some of the ebrochures. We can also see in the results that only five e-brochures indicated the sequencing pattern of Move 1 to Move 5 (Akaa Falls, Avu-Lagoon Xavi, Bonwire Kente, Elmina Castle, Kakum National Park). This makes the Move sequencing M1-M2-M3-M4-M5 the third common structure of the e-brochure texts studied. Apart from these sequencing, the only sequence that occurred twice was the M1-M2-M6-M4. It means that the rest of the texts presented different individual sequencing of Moves.

The most complex sequencing of the Moves occurred in the e-brochure of Kintampo Waterfalls as M1-M2-M3-M4-M2-M4-M5M2-M3-M4-M6, indicating that the Moves were scattered on the e-brochure. This pattern suggests that M2, M3, and M4 repeated some of their elements in the same pattern. It also means that that was the only text that presented its Move sequencing in this manner. This complex pattern might be the result of the unedited construction of the destination.

\subsection{Textual Space of the Moves in the E-Brochure}

The third arm of the schematic structure of genres in the Swales ESP approach is textual space. Textual space demonstrates the attention given to each Move. In this research, the number of words contained in the Moves was used to establish the textual space. It means that words formed the basis for counting the textual space in each text, although another part of the analysis (multimodal) existed to reinforce the importance of the rhetorical strategies. In other words, individual words were counted to get the number of words in each Move. Because the e-brochures were extracted online, they were converted to Word document format in Microsoft Office to assist the counting process. This was to find out the attention given to a particular Move to draw the minds of readers or potential visitors to what is needed to know about the tourist destinations. Table 4 illustrates the results of the specific number of words used in constructing the various Moves. 
Table 4: Textual space distribution in the tourist e-brochure

\begin{tabular}{lllllllll}
\hline Texts & M1 & M2 & M3 & M4 & M5 & M6 & M7 & Total \\
\hline Aburi & 3 & 304 & 77 & 99 & - & 6 & - & 489 \\
Ada & 3 & 92 & 273 & 48 & - & 3 & - & 419 \\
Akaa & 2 & 152 & 53 & 26 & 2 & 11 & - & 246 \\
Avu-La & 2 & 104 & 171 & 175 & 13 & - & 31 & 496 \\
Bonwire & 2 & 849 & 108 & 111 & 2 & - & - & 1072 \\
Cape Ca & 3 & 569 & - & 56 & 15 & - & - & 643 \\
Christ & 3 & 647 & 123 & 50 & 22 & 15 & - & 860 \\
Elmina & 2 & 667 & 245 & 82 & 23 & 22 & - & 1041 \\
Fuller & 2 & 211 & - & 23 & 2 & 22 & - & 260 \\
Kakum & 3 & 202 & 200 & 410 & 2 & 7 & - & 824 \\
Kintampo & 2 & 394 & 218 & 44 & 4 & 7 & - & 669 \\
Komfo & 4 & 659 & - & 34 & - & 23 & - & 720 \\
Kpetoe & 4 & 74 & 143 & 93 & - & - & 57 & 371 \\
Bosomt & 2 & 749 & 88 & 194 & - & 18 & - & 1051 \\
Afadjato & 3 & 299 & 201 & 176 & - & 19 & 25 & 723 \\
Nchiraa & 2 & 185 & - & 15 & - & 27 & - & 229 \\
Nzulezu & 3 & 557 & 134 & 173 & - & 19 & 35 & 921 \\
Tini & 2 & 228 & - & 14 & 2 & 15 & - & 261 \\
Wli & 2 & 179 & 137 & 203 & - & 14 & 91 & 626 \\
Zenga & $\mathbf{4}$ & 188 & 174 & 142 & - & 19 & 112 & 639 \\
Total & $\mathbf{5 3}$ & $\mathbf{7 3 0 9}$ & $\mathbf{2 3 4 5}$ & $\mathbf{2 1 6 8}$ & $\mathbf{8 7}$ & $\mathbf{2 4 7}$ & $\mathbf{3 5 1}$ & $\mathbf{1 2 5 6 0}$ \\
Average & $\mathbf{2 . 7}$ & $\mathbf{3 6 5 . 5}$ & $\mathbf{1 5 6 . 3}$ & $\mathbf{1 0 8 . 4}$ & $\mathbf{8 . 7}$ & $\mathbf{1 5 . 4}$ & $\mathbf{5 8 . 5}$ & $\mathbf{6 2 8}$ \\
\hline
\end{tabular}

Table 4 displays the distribution of textual space in the tourist destination e-brochures. It can be seen that the total number of words counted in all the 20 texts was 12,560, with an average of 628 words per text. Table 4 also displays the textual space in the individual texts. Regarding the textual space given to each Move generally, Providing Background Information (M2) seems to be given the largest space in terms of the number of words. From Table 4, we can see that the second Move (Providing Background Information) has the highest number of words, followed by Move 3 (Detailing Tourist Destinations). The overall average number of words contained in Move 2 is almost as twice many as Move 3. The highest number of Move 2 may be due to the fact that providing the background information of the text as a means of helping customers or potential visitors to appreciate the history and nature of a tourist destination and the reason for its existence. This Move is a means of explaining each destination to the readers. The historical background of the destinations in itself is a way of arousing the interest of readers to decide on visiting the destination. In other words, the readers get first-hand information on the nature of tourist destinations they want to visit because they need to understand fully what they are about to visit. The second highest textual space, Move (3), appears not surprising because everyone would expect e-brochures to provide the exact events and activities one can go through to achieve the goal of visiting such interesting places. This Move (3) seems to be taken from the general background information of the destinations to serve the purpose of specifying the exact activities a potential tourist can go through and the services offered to satisfy the curiosity of the customer. This Move is very important because it is the main event/activity customers expect to see to decide on visiting a destination.

Besides the two Moves with the largest textual spaces, the results in Table 4 show that Move 4 (Providing Service Information) came as the third Move in terms of textual space, followed by M7 (Urging Action), M6 (Providing Extra Information), M5 (Soliciting Response), M1 (Identifying Tourist Destination) in that order. This means that the next important Move to the first two Moves (2 $\& 3$ ) is Move 4. What the ordering of the textual space indicates is that more attention is given to the historical background to provide enough information to detail the potential tourists to understand how the destinations came into being. After this, more space is created for the main activities that the tourists can be directly involved in visiting the destination, which can also motivate the tourist to experience the reality of the destination. The next largest textual space is given to Move 4 because the tourist needs detailed information about his transportation and what will make the tourist comfortable in getting to the destination. Move 4 provides information on location, mileage, accommodation, entrance fee, feeding, and refreshment for decision-making before setting off to visit the destinations. These issues deal with the financial power of the individual deciding to visit the destination, so detailed information is provided for the customer to be conscious of the expected amount to spend in traveling to see. 
The Moves which did not receive much attention were Move 1, 5, and 6, which had 2.7, 8.7, and 15.4 words respectively. In terms of their frequency in all the texts, it is not surprising that Moves 5 and 6 did not occur in all the e-brochures (see Table 2), unlike Move 1. Although Move 1 occurred as the names of the destinations in all the texts studied, it was the least in terms of textual space. Because Move 1 comprised the names of the destinations, there was no need to use many words to construct them as they could be easily identified from one another. As discussed earlier in this chapter, Move 1 contains important words to communicate such information to readers to know what the destinations represented in each situation. This makes all the communicative parts of the e-brochure text very important in contributing to information or advertising property.

Concerning the textual space in the individual text, the longest texts had more than one thousand words. These texts included Bonwire Kente (1072 words), Lake Bosomtwe (1051 words), and Elmina Castle (1041 words). The shortest texts were Nchiraa Waterfalls ( 229 words), Akaa Falls (246 words), and Fuller Falls (260 words). This implies that the difference between the longest text which is around one thousand words and the shortest ones which are less than three hundred words is very wide. Those very long texts produced more historical background information for readers to appreciate their formation and nature.

Despite the fact that Move 2 was generally identified as the Move with the largest textual space, it was not all the Move 2 in each text that received more textual space than the other Moves. For instance, three of the texts, including Akaa Falls, Fuller Falls, and Nchiraa Waterfalls, had their Move 2s smaller than their respective Move 3s in terms of textual space (see Table 4). However, the individual texts that had the largest textual space of Move 2 were Bonwire Kente (849 words), Lake Bosomtwe (749 words), Elmina Castle (667 words), and Christianborg Castle (647 words). These numbers suggest that their respective Move $2 \mathrm{~s}$ were very long, giving readers more information about the background of the destinations.

\section{Conclusion}

The main purpose of this research was to explore the Ghanaian tourist destination e-brochure as a genre from Swales' (1990) approach to genre analysis. The thorough study of the rhetorical and lexico-grammatical features of the Ghanaian tourist destination e-brochure indicates that the text is a distinct genre with a seven-Move structure (Identifying Tourist destination, Providing Background Information, Detailing Tourist Destination, Providing Service Information, Soliciting Response, Providing Extra Information, and Urging Action) to inform and attract potential tourists to pay a visit to a particular tourist destination. The discussion showed that some of the Moves confirmed some studies in the literature but also set aside some Moves as being unique to Ghana, especially providing extra information to readers. The results emphasized three (Identifying Tourist destination, Providing Background Information, and Providing Service Information) of the Moves being presented in all the texts studied. This implies that these three Moves are central to the construction of a new brochure for tourist destinations in Ghana. The common sequencing of the Moves was found to be arranged from Move 1 to 4 . In terms of textual space given to the Moves, the second Move occupied the largest space in the tourist e-brochures studied. This study has indicated that Swales' ESP approach to genre analysis can produce an important understanding of the typical features of a particular genre, in this case, the tourist e-brochure. Since tourist destination brochures are mostly made up of text, images, and videos, it is recommended that a multimodal perspective of genre analysis is conducted to appreciate the entire text fully because only the written text was analyzed in this research.

Funding: This research received no external funding

Conflicts of Interest: The authors declare no conflict of interest

\section{References}

[1] Afful, J. B. A., \& Kyei, E. (2020). Move Analysis of letters of recommendation written by lecturers in a Ghanaian university. Journal of English Language Teaching and Applied Linguistics, 2(5), 01-11.

[2] Alali, B. A. (2017). A genre-based analysis of tourist travel guides. [Unpublished dissertation], Kulliyah of Languages and Management, International Islamic University, Malaysia.

[3] Bakah, E. K. (2010). Analyse du discours oral des guides touristiques et du discourse écrit des guides de voyage: Régularités discursives didactiques. A doctoral thesis, Universite de Strasbourg.

[4] Bhatia, V. K. (1993). Genre analysis: Theory, practice, and application. Burnt Mill, Harlo, Essex, England: Longman.

[5] Bhatia, V. K. (2005). Generic patterns in promotional discourse. In H. Halmari \& T. Virtane. Persuasion across genres: A linguistic approach (pp. 213-228). Amsterdam: John Benjamins.

[6] Boakye, K. A. (2012). Whither oil and tourism? Assessing the potential implications of Ghana's oil and gas production in tourism in Ghana. Journal of Business and Enterprise Development, 3, 96-106. 
[7] Coltman, M. M. (1989). Tourism marketing. New York: Van Nostrand Reinhold.

[8] Getz, D. \& Carisen, J. (2006). Quality management for events. In B. Prideaux, G. Moscardo \& E. Laws (Eds.), Managing tourism and hospitality services: Theory and international application (pp. 145-155). UK: Biddles Ltd.

[9] Henry, A. \& Roseberry, R. L. (1998). An evaluation of a genre-based approach to the teaching of EAP/ESP writing. TESOL Quarterly, 32(1), 147-156.

[10] Hiippala, T (2012). The localization of advertising print media as a multimodal process. In W. L. Bowcher (Ed.), Multimodal texts from around the world: Linguistic and cultural insights (pp. 97-122). London: Palgrave Macmillan.

[11] Hiippala, T. (2013). Modeling the structure of a multimodal artifact. Ph.D. thesis, Department of Modern Languages, University of Helsinki. URL: http://hdl.handle.net/10138/41736

[12] Hsieh, H. F., \& Shannon, S. E. (2005). Three approaches to qualitative content analysis. Qualitative health research, 15(9), $1277-1288$.

[13] Hüttner, J. (2010). Purpose-built corpora and students writing. Journal of Writing Research, 2(2), 197-218.

[14] Iborra, A. \& Garrido, M. F. R. (2001). The genre of tourist leaflets. PASAA, 32, 71-81.

[15] Ip, J. Y. L. (2008). Analyzing tourism discourse: A case study of a Hong Kong travel brochure. LCOM Papers, 1, 1-19.

[16] Irimiea, S. B. (2018). The relationship between the language of tourism, tourism, and sociology. European Journal of Social Sciences Education and Research, 5(2), 138-151.

[17] Kang, N. \& Yu, Q. (2011). Corpus-based stylistic analysis of tourism English. Journal of Language Teaching and Research, 2(1), 129-136.

[18] Kathpalia, S. S. (1992). A genre analysis of promotional texts. Ph.D. Thesis, National University of Singapore.

[19] Kyei, E., \& Afful, J. B. A. (2021). Schematic structure of letters of recommendation written by lecturers of a public university in Ghana. Iranian Journal of English for Academic Purposes, 10(2), 37-54.

[20] Larmolenko, S. \& Schneider, P. (2016). Destination image representation online: Content analysis of Ukraine travel-related websites. Travel and Tourism Research Association, 10. Accessed from https://scholarworks.umass.edu/tra

[21] Luo, J. \& Huang, T. (2015). Genre-based analysis of American tourism brochure. Open Journal of Social Sciences, 3, 200-2008.

[22] Miller, C. R. (1984). Genre as social action. Quarterly Journal of Speech. (70), 151-167.

[23] Molina, A. \& Esteban, A. (2006). Tourism brochures: Usefulness and image. Annals of tourism research, 33(4), $1036-1056$.

[24] Mongkholjuck, C. (2008). A genre analysis of tourist attraction leaflet produced and distributed in Thailand. Unpublished Master_s Thesis, Kasersart University, Thailand.

[25] Nguoi, C. C. L. (2016). Travel brochures for teaching products/service descriptions. The English Teacher, 45(1), 31-44.

[26] Öztürk, B. \& Şiklar, E. (2014). Analysis of a Turkish tourism brochure: Kemer. The Journal of Academic Social Science, 2(1), $321-333$.

[27] Polkanova, N. \& Kozakov, S. (2014). Web-content analysis of the major Spanish tourist destinations evaluation by Russian tourists. International Journal of Humanities and Social Sciences, 8(11), 3638-3645.

[28] Proborini, R. W. D. (2013). Genre analysis of tourism brochures. Unpublished master's thesis, Faculty of Humanities. Dian Nuswantroro University.

[29] Salim, M. A. B., Ibrahim, N. A. B. \& Hassan, H. (2012). Language for tourism: A review of the literature. Procedure-Social and Behavioral Sciences, 66, 136-143.

[30] Sinraksa, D. (2009). A genre-based approach to 'describing the attraction' moves in tourist leaflets of TAT. A master's project, Srinakharinwirot University.

[31] Sun, X. (2009). Stylistic analysis of UK's online tourist information text. Unpublished MA thesis, Dalian Maritime University.

[32] Swales, J. (1990). Genre analysis: English in academic and research settings. Cambridge: Cambridge University Press.

[33] Tulud, D., Mosquera, H. J., \& Algouti, M. A. L. T. E. (2021). Methodology Section of Graduate School Thesis Manuscripts: A Genre Analysis Probe of Rhetorical Structure. Journal of English Language Teaching and Applied Linguistics, 3(9), 36-52.

[34] Vareiro, L., Ribeiro, J. C. \& Renoaldo, P. C. (2019). What influences a tourist to return to a cultural destination? International Journal of Tourism Research, 1-11. DOI:10.1002/jtr.2260

[35] Williams, F. \& MacLeod, M. (2006). Tourism development: Hardcore or soft touch? In B. Prideaux, G. Moscardo \& E. Laws (Eds.), Managing tourism and hospitality services: Theory and international application (pp. 126-144). UK: Biddles Ltd. 